\title{
Peter Jackson's King Kong (2005): A Critique of Postcolonial/Animal Horror Cinema
}

\author{
Marwa Essam Eldin Fahmi ${ }^{1}$ \\ ${ }^{1}$ College of Foreign Languages \& Translation, MISR University for Science \& Technology, Giza, Egypt \\ Correspondence: Marwa Essam Eldin Fahmi, College of Foreign Languages \& Translation, MISR University for \\ Science \& Technology, Giza, Egypt. E-mail:drmarwaalkhayat@yahoo.com
}

Received: March 7, 2017 Accepted: March 26, 2017 Online Published: May 30, 2017

doi:10.5539/ells.v7n2p15 URL: http://doi.org/10.5539/ells.v7n2p15

\begin{abstract}
The current study examines the fictional screen figure King Kong - as envisioned by the New Zealand director Peter Jackson in his 2005 remake - to question European ambivalence towards the Self/Other binary division. The modern 2005 Kong acts as a counter visual icon to the Eurocentric version of colonialist ideologies to expose their hypocrisy and myth-making colonial history. The present study is an attempt to integrate the visual narrative of King Kong (2005) into the framework of Postcolonial paradigm and within the theory of Adaptation to highlight the points of departure undertaken by the Postcolonial director Peter Jackson. The study seeks to establish Jackson's revisit of a prior work as a "willful act" to reinterpret the screen figure Kong as a "Subaltern" subject whose quest for a voice is central to the film's message. The dialogic relationship between the old and the new cinematic narratives is investigated to challenge Essentialist Western View of "Othering" so as to provide a Postcolonial revision of a fluid relationship between a prior work and a belated one. Thus, the aim of the present study is to deconstruct stereotypical representations, to historicize and contextualize Kong as a cultural and historical metaphor in Postcolonial Cinema. Animal Studies can offer new interpretations of how nonhuman animals can deconstruct the ontological Western discourses of rationality and capitalism within Postcolonial Cinema to rethink the boundaries that separate human and nonhuman.
\end{abstract}

Keywords: "Subaltern" subject, theory of adaptation, ethnographic/jungle cinema, postcolonial cinematic Gaze, animalization, exoticism

\section{Introduction}

\subsection{Aim and Scope}

"Western spectator's eyes have been "imperialized" throughout the history of Hollywood cinema" (Kaplan, 1997, p. 219).

The current study examines the fictional screen figure King Kong — as envisioned by the New Zealand director Peter Jackson in his 2005 remake - to question European ambivalence towards the Self/Other binary division. The modern 2005 Kong acts as a counter visual icon to the Eurocentric version of colonialist ideologies to expose their hypocrisy and myth-making colonial history. Thus, the aim of the present study is to deconstruct stereotypical representation, to historicize and contextualize Kong as a cultural and historical metaphor in Postcolonial Cinema.

Deriving impetus from Animal Rights and Environmentalist Movements, human-animal relations have become the subject of attention within discourses as wide-ranging as History, Anthropology, Geography, Gender Studies, Art History and Literary Criticism (Fudge, 2002). The academic field of Animal Studies encompasses all of these perspectives that have emerged in popular culture, literary studies and historical accounts (Burt, 2002, Bekoff, 2007). In What Animals Mean in the Fiction of Modernity (2008), Philip Armstrong argues that "animals have significances, intentions and effects quite beyond the designs of human beings" (Armstrong, 2008, p. 2). Meanwhile, in the 2002 edition of the Empire Writes Back, Bill Ashcroft, Gareth Griffiths and Helen Tiffin observe that "interrogation and exploration of the relationships between powerful human groups and what they have traditionally designated as "animal" is important in Postcolonial studies" (Ashcroft et al., 2002, p. 214).

The present study is an attempt to integrate the visual narrative of King Kong (2005) into the framework of Postcolonial paradigm and within the theory of Adaptation to highlight the points of departure undertaken by the 
Postcolonial director Peter Jackson (1961) to explore the following pivotal research questions:

1) How the power relation between the "Self" and the "Other" is dealt with? Is it opposed? Renegotiated? And how is it performed within the visual world of the filmic text?

2) Can King Kong in the 2005 remake be set as a "Subaltern" subject? And how his ethnicity can be a powerful tool of challenging and most importantly breaking the stereotypical image?

3) How are the encounters between humans and nonhuman - animals, nature and landscapes - portrayed in and shaped by cinematic techniques?

The study seeks to establish Jackson's revisit of a prior work as a "willful act" to reinterpret the screen figure Kong as a "Subaltern" subject whose quest for a voice is central to the film's message. The dialogic relationship between the old and the new cinematic narratives challenges Essentialist Western View of "Othering" to provide a Postcolonial revision of the fluid relationship between a prior work and a belated one. Linda Hutcheon - in $A$ Theory of Adaptation (2006) - describes the act of adaptation as "an acknowledged transposition of a recognizable other work or works; a creative and an interpretative act of appropriation; an extended intertextual engagement with the adapted work" (Italics mine, Hutcheon, 2006, pp. 8-9), therefore, adaptation is a work that is second without being "secondary" or "inferior". Jackson's recreation of 1930s New York and the computer-generated Kong demonstrate enormous steps forward in the technical aspects of filmmaking. And, in sharp contrast to the original 1933 film and the embarrassing 1976 remake, Jackson begins the film with a collage of Depression-era America. He even includes among the crew of the ill-fated ship a sailor reading Joseph Conrad's Heart of Darkness.

\subsection{An Appraisal of the Fictional Silver Screen Figure, King Kong}

King Kong is the most famous fictional character that ever made to the silver screen. King Kong (2005) is a remake of the original 1933 film directed and produced by Merian C. Cooper and Ernest B. Schoedsack, the most recent incarnation of Kong, the longest running three hours and eight minutes and the winner of three Academy Awards for visual effects, sound mixing and sound editing. Moreover, it is the most famous Jungle film about the twenty-five foot gorilla that is considered as "an iconic image in global culture" (Sorenson, 2009, p. 11). King Kong (2005) depicts the hybrid ape-man on screen as the "Eighth Wonder of the world" as stated by the film director in both versions - Carl Denham. The image of Kong atop the Empire State has become part of the cinematic lexicon of cultural icon in both the old and the revisited versions, that is, the black Kong has become a metaphor for the global subjugated nations as expressed in Lupoff's description "Kong is us" (Lupoff, 2005, p. 25).

It is noteworthy that Merian Cooper came up with the name "Kong" "as a result of having unconsciously internalized stories about the exploration of the Congo" (Manlove, 2012, p. 125). Thereby, the tale of King Kong is an allegory of slave trade shipped to America as tamed cargo to be exhibited to the public shackled on a platform and Kong becomes "the projection of Anglo-American's worst nightmare, the race riot" (Rice, 2003, p. 194). Being a signifier of the black identity, Kong is marked as a threat to the White society. In the 1933 film, a man - while starts watching Kong on the stage - says: "I hear it's a kind of a gorilla". The female seatmate answers: "Gee, haven't we got enough of them in New York". The old version underscores white fears depicting a "Manichean reality for colonial/ racist fantasists" (Torgovnick, 1990, p. 53). Kong's uncontrollable violence requires the deployment of heavier artillery, namely, the war against the apish terror has become a national affair.

Briefly, Carl Denham - in the two versions (1933 and 2005) - hires a ship and crew to cinematically colonize an unknown island. He recruits a blonde white actress, Ann Darrow, promising her money, adventure and fame. The mysterious island is sighted and turns out to be an ideological manifestation of the racial knowledge of the Western world that has been accumulated during the European history of discovery. What is striking in the 2005 remake is that Skull Island's topography of racism identifies Kong and the Conradian jungle as signifiers of savagery and primitivism. In the belated film, Skull Island is a prehistoric jungle born from Joseph Conrad's Heart of Darkness (1899) read by a young white cabin boy—Jimmy—on the ship throughout the sea voyage. An enormous wall separates the living space of the island population depicted as primitive dark-skinned savages incapable of bringing Nature under their control trying to appease it with female sacrifices offered to a giant ape. The white Ann Darrow is kidnapped and offered to the apish monster. She is rescued by the white savior John Driscoll-the film's scriptwriter-and Kong is defeated by the Crew's superior Weapons: ammunition, gas-bombs and explosives to be exhibited in the most horrible and dehumanized ethnographic spectacle in Broadway Theatre by the cruel schemer Carl Denham. 
The implicit racism of Cooper's King Kong, when analyzed according to the symbols it presents, offers a fascinating portrait of the "common" white man's perception of segregated America and his perception of his African-American countrymen. Cooper's original came out of an era of ethnographic narratives-like Cooper's Grass (1925) and Chang (1927) which grafted adventure stories and a decidedly white-colonialist worldview on exotic lands and their peoples. King Kong (1933) is a fantasy spin on the ethnographic narrative, a naturalist genre founded on a sensationalist wonder of the exotic - those non-white frontiers of civilization. The 2005 Kong has been updated for the globalized twenty-first century for this post-colonial age of political correctness and the use of the digital razzmatazz makes it more technically exhilarating and insightful within the center/periphery dichotomy.

What is unique about the two cinematic narratives is the notion of self-referentiality. The old and the new versions are about "making" a film to enhance the notion of "seeing" and to draw the attention to the process of making things seen in order to "point the camera to itself and its history of production" (Telotte, 1988, p. 390), that is, the "historical gun/camera/trope" (Erb, 1998, p. 34):

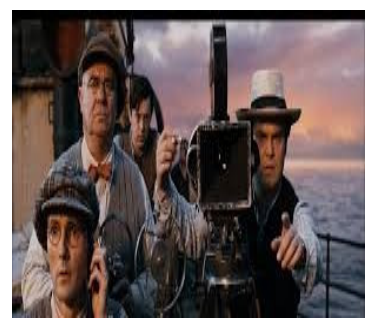

Figure 1. Carl Denham's ethnographic/jungle film

Carl Denham's enterprise is about the making of an ethnographic film which depicts the screams of the blonde heroine and the roar of the giant gorilla. The film itself is "a monster, a hybrid of the scientific expedition and fantasy genres" (Rony, 2000, p. 243). Both cinematic versions of King Kong (1933 and 2005) are successfully modeled on the narrative of an expedition film that uses variations on "the "complex discovery" plot: the monster first appears or is created (onset); it is then noticed by the human protagonists (discovery); the horrible existence is acknowledged (confirmation) and the film ends with a fight to the death between the human and monster (confirmation)" (Carroll, 1990, p. 99). Finally, the imagery of dense fog or mist in the two cinematic films is of great visual significance to allude to Skull Island deploying the trope of dreaming "with grey-miasmic connotations of obscurity, primordialness, fantasy, dream-likeness and ghostly "presence"" (Carroll, 1984, p. 129).

On the surface level, the revisited King Kong is a romantic, cinematic fairy tale about the monstrous gorilla that falls in love with the beautiful white woman. This is a reminiscent retelling of Marie Laprine de Beaumont's Beauty and Beast (1756), a link stated in the final cinematic spectacle by Denham: "It was Beauty that killed the Beast". The story has also been interpreted as a tale about modern civilization's intervention into Nature. The black gorilla is uprooted from its original setting to be exploited in an urban civilization and eventually defeated by its war technology. On the deeper level, the narrative takes the viewer to the Great Depression in 1933 New York and Kong's rampage is seen as a symbol of the national resentment of the white civilized nation. The real-world reference is a threat to racially segregated society posed by a rebellious non-white inside the country (former slaves and recent migrants) as well as outside (global uprising at the colonial periphery). The black beast rapist discourse - within the imperialist interpretation- has rationalized white execution of black man as a moral duty to protect white womanhood. At the time of the production of King Kong (1933), the alleged rape of white women by black man was a familiar issue. In the language of images, King Kong offers pejorative images depicting African-American as rapists or associating them with apes, thus, the viewers heading off to see King Kong were prepared to understand that this film is not "merely a horror film version of Beauty and the Beast" (Klaw, 2005, p. 1123). Finally, Kong is an embodiment of Freud's id, the dark, animal shadow that lurks in the human psyche as well as of Rousseau's man in a state of nature untainted by modern life.

\section{Picturing the Other in Postcolonial Discourse}

\subsection{Definitions and Perspectives}

Postcolonial Studies are an interdisciplinary field concerned with the colonial past as well as postcolonial 
identity (Italics mine, Stam, 2000, p. 292). What is crucial is how the colonizer and the colonized are categorized into several binary oppositions which establish the core difference between the two and address subject positions. Some of these are "cultural/natural", "civilized/primitive", "rational/irrational" and "white/black". The field of Postcolonial Studies engages in examining how such issues are represented in all sorts of texts such as literature, theatre or cinema.

The prefix "post" would seem to indicate that before the emergence of "Postcolonial Literature" there must have been "Colonial Literature". "Post-colonial"-which is hyphenated - refers to literature which has emerged after the Second World War which heralded the end of European colonial empires. "Postcolonial Literature" and "Colonial Literature", however, need closer scrutiny. Elleke Boehmer, in Colonial and Postcolonial Literature (1995), draws attention to the fact that were these terms to be taken at face value, Britain would have to be treated "as a postcolonial country from the moment when the last Roman soldier left the British Isles, in which case works such as Beowulf or The Canterbury Tales would have to be interpreted as postcolonial work" (Boehmer, 1995, p. 1). Boehmer suggests to limit the field of research by concentrating on the modern colonial empires that have emerged over the last four or five centuries: "texts described as colonial or colonialist are taken to be those like King Solomon's Mines or Kipling's poems which exhibit a tinge of local colonial color, or feature colonial motifs - for example the quest beyond the frontiers of civilization" (Boehmer, 1995, p. 2).

The distinction between "colonial" and "colonialist" literature is of primary importance as the first term refers to literature which partly reflects colonial experience whereas the second term refers to literature which is explicitly concerned with the idea of colonial expansion and which gives an account of reality from the perspective of a European colonizer. In The Empire Writes Back (1989), Ashcroft et al. suggest that the term "postcolonial" should refer to all cultures affected by imperial expansion-from the beginnings of colonialism to the present day. They argue that the expansion of colonial empires in previous centuries exerted a considerable influence on historical processes that have lasted down to our times, hence, literatures labeled as African, Australian, and Canadian or Indian that have created during or after the time when colonial empires flourished are postcolonial (Ashcroft et al., 1989, pp. 1-2). The era of imperial domination left behind ills in dire need of remedies and it was not until the late of 1970s that the term "Postcolonial" started to be used by literary critics to investigate "cultural effects of previous imperial expansion"( Ashcroft et al., 2000, p. 168).

Postcolonial - as a term — is ideological not merely temporal in the sense that the subjugated selves seek to assert their historical presence. Postcolonial literature, therefore, encompasses not only those works which are created after the end of the Empire, but also all those works which discuss and interrogate the issue of relationships between the colonizer and the colonized and in particular those masterpieces which offer an alternative to "canonized" colonial fiction as explained by Boehmer: "postcolonial writer sought to undercut thematically and formally the discourses which supported colonization - the myth of power, the race classifications, the imagery of subordinated" (Boehmer, 1995, p. 3). There is a general consensus among scholars that postcolonial writings mostly represent the focus on "cultural difference" (Ashcroft et al., 1989, p. 4; Bhabha, 1994, p. 233; Thieme, 2001, p. 6; Mohanty, 2003, p. 106). The depiction of such a difference in Postcolonial fiction is a "quest for the voice" (Bhabha, 1994, p. 177). This approach is in accordance to the argument of G. Spivak-who in her illuminating Essay "Can the Subaltern Speak?" (1993) — suggests that the Western act of benevolence is an act of violence since the intellectual tradition of the Western world attempts to deny the voices of the oppressed (Spivak, 1993, p. 83), thus, the quest for the Other's voice is an effective way to study the desires and aspirations of the oppressed. What is striking is "the construction of the Other that is fundamental to the construction of the Self” (Ashcroft et al., 2000, p. 156).

\subsection{Encountering the Exotic Other}

George Friedrich Hegel was the first to introduce the concept of the "Other" defining it as being the opposite to the Self. He argues that the "Other" is "essential to the realization of self-consciousness" (Dias, 2013, p. 2). The concept of "Othering" is a process created by imperial discourses, yet it exposes the colonial state of ambivalence as well as of hypocrisy. In a similar vein, the natural world is in a symbiotic relationship with nonhumans, that is, the identity of human depends on the idea of nonhuman: "Human is a category only meaningful in difference; that innate qualities that are often claimed to define the human - thought, speech, the right to possess private property... qualities of humanness are actually conceivable through animals; that is; they rely on animals for their meaning" (Fudge, 2002, p. 10). Speciesism - manipulated to justify the domination of nonhuman animals - is defined by Peter Singer in Animal Liberation (2002) as "a prejudice or attitude of bias in favor of the interests of members of one's species and against those of members of other species" (Singer, 1975, p. 6). Thereby, Speciesism is a form of oppression reinforcing other systems of oppression like Classism and Sexism. Fear and enmity — associated with the wilderness — shaped the eighteenth and nineteenth literature to 
tame natural world for the Western Social Order: "the wilderness is the antithesis of civilization; it is barren, terrible, even sinister, not just the home of the savage but his natural home. The wilderness and the savage were as one; they were obstacles to be overcome in the march of progress and civilization" (Italics mine, Smith, 2008, p. 20).

Colonized people are subject to "Othering" and stereotyping with regard to their ethnicity. Ethnicity is understood in terms of an account for "culture, tradition, language, social patterns and ancestry, rather than the discredited generalizations of race with its genetically determined biological types" (Ashcroft et al., 2000, p. 75). Thus, ethnicity is a "positive self-perception that offers certain advantages to its members" (Ashcroft et al., 2000, p. 75). The binary stigmatization between Man and the Monster is at the heart of the present study to depict Kong's transgress into the civilized world. Kong is culturally or ethnically different and he is constructed as a monstrous "Other", yet, the White conquerors seek to catch the black primitive Kong to assert their superiority. This difference is threatening and a site of danger, hostility and aggression towards the "Other". The colonial "Self" is ambivalent: the "Other" is totally different but also essential for the coherence and stability of the "Self". This state is defined as the "essentializing of race" (Bennett \& Nicolas, 2009, p. 238) in which the "Western notions of human identity itself as universal or unchanging may be recognized as a historical construct constituted by the exclusion, marginalization and oppression of racial Others" (Bennett \& Nicolas, 2009, p. 238).

Thus, colonialist ideologies function to fix and normalize the "Other" as inferior, savage and less human. The image of King Kong on the top floor of the Empire State Building is an embodiment of the clash between beastly desire and civilized culture, between the nobility of the animal and the destructive drive of human beings as the scene captures the essence of Euro-Western discourse on animality. The gorilla encapsulates many centuries of mythology: a creature from the depths of the jungle and an abductor of women, the ape is caught between animal impulse and human morality.

Skull Island can be interpreted within Mary Louise Pratt's notion of "Contact Zone" to foreground spaces where cultures meet, clash, and grapple with each other, often in contexts of highly asymmetrical relations of power such as colonialism or slavery. She describes the "contact zone" as a "space in which peoples geographically and historically separated come into contact with each other and establish ongoing relations usually involving conditions of coercion, radical inequality and intractable conflict" (Pratt, 1992, p. 6). In Primate Visions (1989) Donna Haraway argues that the simian has long occupied the border zone between the "mythic poles" of nature and culture, between "the constitution of imaginative worlds and of actual bodies"; primate representation has always been a "constrained and contested mode of storytelling" (Haraway, 1989, p. 5). By choosing to locate the beast's origins within a fictional locale, the filmmakers attempt to avoid any direct implications towards Africa or the Caribbean, but the fact remains that Skull Island represents a popular colonial interpretation of the "dark continent". Not only is the island home to Kong and a group of Black natives, it is also inhabited by a large number of prehistoric beasts. Dinosaurs are seen to coexist with the indigenous peoples.

Darwinian interpretations reconfigure the simian as a related progenitor to human beings arguing that "man" has undergone an "extraordinary amount of modification, chiefly in consequence of the great development of his brain and his erect position", it should nonetheless be remembered that he is one "of several exceptional forms of Primates" (Darwin, 1871, p. 154). The public uproar against Darwin's claims of relation is well known, and yet the story of a fundamental metaphysical relationship between human and nonhuman primates continues to fascinate storytellers and audiences. Neo-Darwinian social discourses on the "threat" of degenerate sexualities have continued the historical association of wild men and apes with tales of the abduction of human women. Freud's story of the primal horde and humanity's original patricidal family certainly owes much to Darwin's Evolutionary Theory; yet Freud would take the story of animal origins a step further to plant animal desires deep within the structure of the human psyche. Generally, apes evoke long-standing historical anxieties about the boundary between human selfhood and animal degeneration.

Despite the transformations in the visual representation of Kong in the 1933 and 2005 versions, both films remain embedded in the Western metaphysics of human-animality dichotomy. Kong serves as more than a symbolization of gender and race relations in contemporary culture; he remains also a figuration of anxieties over the border between human and animal. Both versions embody historical discourses of the brutish tendencies of the wild outsider along the border of civilization, the beast's libidinous threat to the civilized human. At the same time, the human-like attributes of the animal, and indeed its ultimate persecution by humanity evoke outrage at the human masculine/military machine intent on destroying it through acts of aggression. The ape is represented as both origin and antithesis of what constitutes humanness itself.

Denham's dangerous journey into the unexplored regions of the world reflects a popular fascination with wild 
and unknown realms that is related directly to the tail end of colonialism and the growth of American cultural imperialism. The United States is commonly considered not to have a history of colonialism correspondent to that of the European powers, particularly in Africa, and even the imperial designation is foresworn in favor of the more nebulous term "superpower". But the experiences of slaves of African descent would tend to suggest otherwise and behind the high-flown rhetoric of liberty and equality under God, there have been many minority communities that have been denied their share of constitutional freedom throughout American history, often due explicitly to their inherent Otherness.

\subsection{Aesthetics of Postcolonial/Animal Horror Cinema}

Basically, Animal Horror Cinema tells the story of how a particular animal commits a transgression against humanity and then recounts the punishment the animal must suffer as a consequence. Thereby, Animal Cinema can be defined as fictional movies where the animal seeks to challenge the predominance of the human through physical violence and it is the dangerous animal that elicits suspense and fear in Animal Horror Cinema (Gregersdotter et al., 2015, p. 3). It is worth mentioning that Animal Horror Cinema has always blurred the distinction between "realist" representation and what it has been able to invent through imagination and special effects. Technological developments and a broad change in the socio-cultural meanings attached to nonhuman primates produce a different narrative emphasis on the two cinematic versions, 1933 and 2005. In 1933 King Kong, stop-motion animation creates a beast both fearsome and fantastic; and in the twenty-first century, WETA's digital-effects team created life-like animals moving through fantastic worlds. The 1933 Kong is depicted as "half-human, half-beast" to create a "Giant Terror Gorilla" that would be seen by audiences as brutish, virulent, and virile. Jackson's story, by contrast, portrays an animal that feels, suffers, and gazes at sunsets (Morton, 2005, p. 33).

Animal Horror genre spotlights on the animal and the natural world in which the wild animal's life is figured as the realm of the primitive while the opposite qualities have traditionally been associated with urban life in the metropolitan. The focus is on the perspectives of Postcolonial Cinema to question ethnocentrism based on the attempts to stop the cannibalistic consumption of the human body. Yet, ironically, the European colonial enterprise was itself a form of consumption. The European colonizers were eating up the non-European world and many societies it had designated as animal rather than as human. Western epistemologies of Empire have imagined the animal and the colonized to inhabit the same subordinate position. In the words of Philip Armstrong, several "of the most potent and durable intellectual paradigms produced by European cultures at the height of their imperialist arrogance owe simultaneous debts to the colonial and animal world" (Armstrong, 2002, p. 414), thus, histories of race and empire have shaped "the field imaginary of species studies from its inception" (Ahuja, 2009, p. 556). This underscores the intricate relationship between Postcolonial Cinema and Animal Studies, as Peter Singer argues that the Western history is characterized by "a tyranny of human over non-human animals, a tyranny causing an amount of pain and suffering that can only be compared with that which resulted from centuries of tyranny by White humans over black humans" (Singer, 1975, p. vii).

Animal Horror Cinema enacts the notion of animal's "disruption" of "the smooth unfolding of Enlightenment ideology" (Armstrong, 2002, p. 415). Just as epistemic colonization has been disrupted by Anti-Colonial struggle, Decolonization and Postcolonial theory, the exploitation of animals and their habitats is sometimes imagined by Animal Horror Cinema as the real horror that forces animals to respond with disturbing violence. Kong's rampage through the streets of New York is an act of disruption and the menace of Blackness is made corporeal to threaten the infrastructure of America's largest metropolitan center. The image of Kong destroying the subway cars demonstrates the very real fear of the destruction of White hegemony by the Black Savage. Monstrosity is essentially visual since the focus is on screen monster to foreground its "bodily disruption" as explained by Stephen Neale in Genre (1980): "the monster, and disorder it initiates and concretizes, is always that which disrupts and challenges the definitions and categories of the "human" and the "natural"" (Neale, 1980, p. 21). The screen figure King Kong is a "paranatural monster" (Russell, 1998, p. 242) since it originates from an unfamiliar part of nature and later transgresses the boundaries of the normal world with its abnormal physical unrealities. Kong enters the realistic space as a physical being that is abnormal due to its origins and by stretching the rules of everyday experience.

Finally, King Kong (2005) - as a Postcolonial film-juxtaposes the naturalistic presence of the flesh (Ann Darrow and the White colonizers) with the fantastic presence of the magical (Kong and the prehistoric creatures). The question of screen animal is central to the history of the cinema. The cinematic construction of the screen animal with its vast array of complex special effect technologies approaches the creation of the animal as a Darwinian being, a creature with the power to feel and to communicate: "By expanding the definition of community to include animals, Darwin's work precipitated the subsequent search for modes of communication 
between animals and human beings" (Lippit, 2000, p. 76).

\subsection{The Colonial/Postcolonial Cinematic Gaze}

"The cinema satisfies a primordial wish for pleasurable looking"-(Mulvey, 1975, p. 9)

The beginnings of cinema coincided with the capricious heights of imperial venture and with an epoch where Europe held sway over vast regions of alien territories and hosts of subjugated peoples. Film was born at a moment "the cinema adopted the popular fictions of colonialist writers like Kipling for India and Haggard Edgar Wallace and Edgar Rice Burroughs for Africa and absorbed popular genres like the "conquest fiction" of the American Southwest" (Shohat \& Stam, 1994, 100). The concept of Postcolonial film is a framework for identifying films produced within and outside of various formerly colonized nations and the fantasy of far away tracts offered "charismatic realms of adventure" (Shohat \& Stam, 1994, 100) since the colonial landscapes have been a thrust for imperial gaze to enjoy an invigorating sense of visual power. The cinema in the 1933 and 2005 King Kong penetrates an unfamiliar and strange zone like a predator seizing its loot of images as raw material to be reworked in the motherland and sold to sensation-hungry spectators and consumers, thus the King Kong films convey the view of the world itself as an exhibition and the cinematic exposure of the dark body nourishes the Western visual/racial inclination boundaries between "Self" and "Other".

The cinema's ability to "fly" spectators around the globe has given them "a subject position as film's audio-visual masters" and the "ontologically" kinetic status of the moving images that depict the imperial conquests and travel has turned "the colonies into spectacle for the metropolis's voyeuristic gaze" (Shohat \& Stam, 1994, p. 103). The colonial camera has anatomized the "Other" giving a holistic portrait of the colonized since the culture of the empire has authorized the pleasure of seizing ethnographic images in which the cinematographers have recorded their own colonial visions and in doing so, they also have drawn clear boundaries between the subject/colonial looking and the object being looked at between traveler and travelled upon.

One way of investigating subject positions and their potential for power or agency within Film Studies is through the analysis of the "gaze" or the "look" of the camera, the characters as well as an insinuated audience. The media of the film differs from other artistic textual media as it "presents us with images in illusory motion" (Bordwell \& Thomson, 1993, p. 3) and "there is always an invisible discursive agency in any cinematic construction" (Stam et al., 1992, p. 170). What is more, the concept of the "gaze" can be compared to "a character's point-of-view which is often connected to other elements such as logic of narrative, dialogue or previous shot" (Stam et al., 1992, p. 162). In Looking for the Other (1997), E. Ann Kaplan develops the "imperial gaze" into what she calls "looking relations" providing a concept which allows an alternative way of understanding cultural and racial differences. The "imperial gaze" centralizes the White Western subject while "looking relations" refer to possible ways of changing a fixed imperialized gaze within the audience.

In "Visual Pleasures \& Narrative Cinema" (1975), Laura Mulvey generally speaks of three types of "looks" in relation to cinema: 1) that of the cinema as it records the pro-filmic event, 2) that of the audience as it watches the final product, and 3) that of the characters at each other within the screen illusion" (Mulvey, 1975, p. 17). Kaplan emphasizes the fact that the gaze has to be situated within a historical time of colonial ways of thinking and relates the binary oppositions to "fear of difference" (Kaplan, 1997, p. 63). The "fear of difference" is a fear of the Other taking over the dominant position within economic and political power. At the peak of colonialism at the end of the nineteenth century, the imperial gaze is reflected in Hollywood cinema: "Hollywood films mimicked the imperial gaze of people [explorers, missionaries, scientists] who travelled to cultures in different lands" (Kaplan, 1997, p. 64). Kaplan mentions several examples such as D. W. Griffith's Birth of a Nation (1915), Tarzan, the Ape Man (1932) and King Kong (1933). Generally speaking, these films and among others in the thirties of the last century were attempts to shift the focus from the economical problems in America over to racial ones.

Within the imperial gaze, it is only the White Westerner who could be in a subject position. However, within the notion of "looking relations", it becomes possible to change subject positions as the former Othered object can now look and speak in relation to his worldview or culture. Herein lies the hypothesis of my study that marks the critical shift of the cinematic gaze from the dominant hegemonic power of the White to Kong in the 2005 remake in which the ape's expressive eyes and face evoke a subjectivity that the earlier 1933 film has not fully captured so as to unfix colonial past and implement a postcolonial identity. The technological and semiotic use of the gaze can be understood as a way in which the film rhetorically equates the way in which the viewer interprets the shot with the fictional animal's understanding of the world. On a semiotic level, close-ups on Kong's eyes and facial expressions signal a psychological bond between human and animal adversaries which likewise implies the 
presence of a human-like internal world in the animal.

Kong as a screen animal has the potential to rebut the dichotomous thinking of Western philosophy that has separated human from animal, mind from body and urban civilization from Nature. Within this rationale, Kong can be viewed as a Deleuzian "body without organs", that is, as a body of becoming, freed from its habituated modes of being and free from conventional expectations as to how it should behave and act (Deleuze \& Guattari, 1987, pp. 149-166). In the 2005 revisit, Kong is a screen figure with a name and a recognizable face signifying a postcolonial identity to undermine humanity's ethnic view of the world, thereby; his sufferings are a symbolic critique of zoos, exhibitions and animal captivity and his sensations are very elegiac and poetic.

\section{Peter Jackson's Joseph Conrad-Inspired 2005 Remake of King Kong}

Joseph Conrad's Heart of Darkness (1899) is recognized as a comment upon the late nineteenth century imperialist "mission civilisatrice". Edward Said claims that what Conrad really criticizes in "the scramble of Africa" (Said, 1994, p. 80) is the West's power-motivated apparatus of self-excuse: "the practice that essentially disguises or obscures [the imperialistic takeover of territory] by developing a justificatory regime of self-aggrandizing self-originating authority [which] interposed between the victim of imperialism and its perpetrator" (Said, 1994, p. 82). What Said means by "justificatory regimes" are the "overmastering narratives" - the imperial self-made narratives that mask the colonial atrocity (Said, 1994, p. 24). The colonial machine has been built on the Western popular imagination demonstrating how "seemingly impartial objective academic disciplines had in fact colluded with and indeed been instrumental in the production of actual forms of colonial subjugation and administration" (Young, 1995, pp. 159-160).

When Marlow recounts his African journey, he outperforms an act of imperial mastery over the continent. He does not just photographically mirror it, but he theorizes, historicizes and politicizes it according to the Western paradigm pointing meanwhile to its strangeness, wilderness and "darkness". The question that poses itself: Does Marlow have any other choice? Can he really do otherwise? Said writes explicitly: "there is no way out of the sovereign historical force of imperialism; it has the power of system representing as well as speaking for everything with its domain" (Said, 1994, p. 26). According to Marlow, the Empire's claim that it civilizes the "dark" regions of the world is just "an idea at the back of it, not a sentimental pretence but an idea and unselfish belief in the idea - something you can set up and bow down before and offer a sacrifice to" (Conrad, 1988, p. 10). The imperial conquest has been codified and mythologized in and through the Empire's legitimizing narratives. As a man of his times, Conrad does not imagine there is Chinua Achebe who would accuse him of racism. Herein lies "Conrad's tragic limitation" (Said, 1994, p. 34) because the only notion he has is that Africa is empty, timeless and "dark". Thus, the "grand narrative" of "mission civilisatrice" has turned out to be a disastrous "sentimental pretence". Conrad is "tragically limited", so he cannot devolve the power struggle from the metropolitan to the local and peripheral one.

\subsection{The Heart of Darkness/King Kong Interplay}

Peter Jackson's 2005 remake of King Kong exhibits a relation to Heart of Darkness which Jackson deploys in the sub-story about the cabin boy, Jimmy, reading Heart of Darkness as the steamer makes its way from Manhattan to Skull Island, the home of King Kong. Peter Jackson's King Kong reinforces the Other-ness of a Congo-like atmosphere and the human-male dominance. The film constructs Skull Island and its inhabitants as "Other" in ways similar to those Chinua Achebe describes when discussing Joseph Conrad's Heart of Darkness in "An Image of Africa". It is quite possible that these are deliberate choices on the part of Peter Jackson who places Conrad's novel repeatedly and prominently in the film, including multiple dialogue sequences in which characters talk about the novella.

Skull Island becomes a clone of Congo. There is a striking similarity between the word "Congo" and the name "Kong", but Skull Island is uncharted in the Indian Ocean. In Heart of Darkness, according to Achebe, Conrad uses mysteriousness, lack of language, frenzy, and common origins to construct Congo as an "Other". In "An Image of Africa", novels such as Heart of Darkness represent Africa as another because of "the desire — one might indeed say the need-in Western psychology to set Africa up as a foil to Europe" (Achebe, 2001, p. 1784). For Achebe, Conrad animalizes the African people, going so far as to deny them language and reducing them to grunts and "frenzy" (Achebe, 2001, pp. 1787-1788). In other words, Conrad's story encapsulates the colonial perspectives of White Europeans. Like animals, the colonial "Other" is a monster not only for his practices, but also because they lack culture and civility as defined by bourgeois Europeans. Western epistemologies - spurred by the rapid colonialism - have shaped the concept of "Self" and the treatment of nonhuman animals along with the colonized "Other".

The 2005 remake adds two new characters to the plot: Hayes, a black officer on the ship and Jimmy the cabin boy, 
a White adolescent. Hayes tries to civilize the White boy by critiquing his behavior and making him read Heart of Darkness:

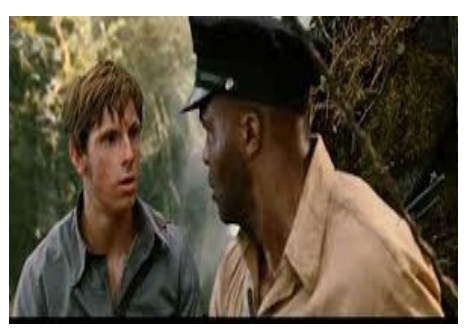

Figure 2. The black-white relationship revisited

As the ship reaches Kong's Skull Island in the film, Jimmy delves further into Conrad's novella allowing Jackson to draw parallels between Marlow's descent into the "horrors" of colonialism in the novella and the ship's passengers' journey into the darkness of Skull Island. What is outstanding is that Hayes has a preexisting knowledge of Conrad's novella providing an interpretation of the events of Heart of Darkness. Hayes - in a voiceover- quotes Conrad: "we are accustomed to look upon the shackled form of a conquered monster, but there - there you could look at a thing monstrous and free. It was unearthly, and the men were- No, they were not inhuman". The quotation evokes Conrad's image of the colonial "Other" rooted in racial discourse of "difference". Thereby, it foreshadows the encounter with the ugly horrid faces of the Skull Island's dwellers as well as the wild roar of Kong.

While the colonizers in Conrad's novella attempt to civilize the black natives of the lands they conquer, Jackson's characters reverse roles making the black Hayes the model of civility attempting to impress his customs upon the unruly Jimmy. It is a relation which Jackson juxtaposes with Kong's subjugation at the hands of Denham. Heart of Darkness allusions represent a Postcolonial act to "write back" to the empires that colonized New Zealand and Congo. Jackson harkens back to the colonialism by essentially rewriting the works and power structure of the imperial enterprise for Postcolonial era.

The film portrays Kong as an "Other" in the first hour and a half. Kong is a mysterious figure as delineated in legends as a creature that is neither beast nor man, but something monstrous, dwelling in an undecipherable smudge on the map, and roars from behind the wall. When Kong appears from the forest, he is mainly obscured by dust and low under-lighting emphasizing his hands, hairiness, size, and shoulders. When Jack asks Carl what he has seen, Carl cannot answer, and Captain Englehorn wonders, "What in God's name was that?". Kong, then, by connection with the "frenzy" and chaos of the native peoples acts as an "Other" from which Jack must rescue Ann.

\subsection{The 2005 Kong's Cinematic Gaze as a Male Protagonist}

During Ann's captivity, the film shifts from depicting the gorilla entirely as a monster or animal to depicting him as a male protagonist. Ann's first presentation is an attempt to placate an angry Kong after her failed escape from him, while the second is to cheer him up while he appears to be sulking because she again attempts to leave him. In the first scene, the camera often looks down at Ann from an upwards angle; in one case, Ann's eyes follow the camera as though the camera is Kong. In the second scene, she performs again; this time, her much of her performance is made with her back to Kong, probably in an attempt to get his attention by ignoring him; because the camera is focused on Ann with Kong in the background.

A few shots later, the audience views Ann from approximately Kong's point of view, as she turns to make her performance directly to him. While Ann is performing for Kong, she is also performing for the audience. Kong reacts to her first performance with laughter, and the release of tension invites the audience to laugh as well — conflating Kong's and the audience's reactions. During these scenes, Ann's performance is not strictly of an attractive or erotic nature - she enacts routines from comedic theatre. However, in the first scene, the frequent exposure of her bare legs and shoulders during Kong's preferred part of the performance-where he pushes her over-indicates that she remains an erotic object to the audience while she remains an object to be only controlled by Kong. In the second scene, her performance fails to please Kong, and she eventually switches to his desired activity: watching the sunset. She then steps into his hand willingly becoming his possession.

The identification with Kong leads to the destruction of the "Othering" established in the beginning of the film. This depends on each individual viewer's response, but the film uses camera angle and emotional manipulation to 
promote identification with Kong. As previously noted, Kong's laughter provokes the audience's laughter. During his rampage in New York, the music is fast, the lighting is highly contrasted, the movement is quick, the background noise is harsh and invasive, and the scenes change rapidly, making the audience feel Kong's agitation. When Ann appears and calms him, the music slows, the lighting becomes muted and diffuse, the background noise fades, and the scenes linger on single, slow-moving subjects. Thus, Kong is established as the male protagonist. The editing and directorial choices encourage the viewers to associate their human reactions with Kong's reactions - laughter, defensiveness, tranquility - breaking down the distinction between the "savage" Other and the "civilized" self. During these sequences, particularly those after the initial chaos in New York, Jack, the "Other" male protagonist is hardly present whereas in Kong's moments of tenderness or joy with Ann-laughing and spinning on the ice with her-he appears most human. In his moments of triumph immediately after rescuing her, he is undeniably a gorilla, beating his chest and roaring, exposing his large teeth seen as "savage" and wild. Kong is without spoken language, and certain scenes emphasize his mysteriousness. While Ann and Kong sit together on the Empire State Building, she tries to convey to him that she thinks the sunrise is "Beautiful". Kong, however, does not respond, and the audience is left to guess of what the gorilla thinks through the use of camera angles, emotion manipulation, and narrative elements - techniques that reinforce the state of identification. This creates a tension between regarding Kong as an animal deserving fear or love and sympathy, and identification with Kong as an ideal "Other".

Ann's interaction with Kong is defined by her gazing at him as exemplified in the scene at the top of the Empire State Building:

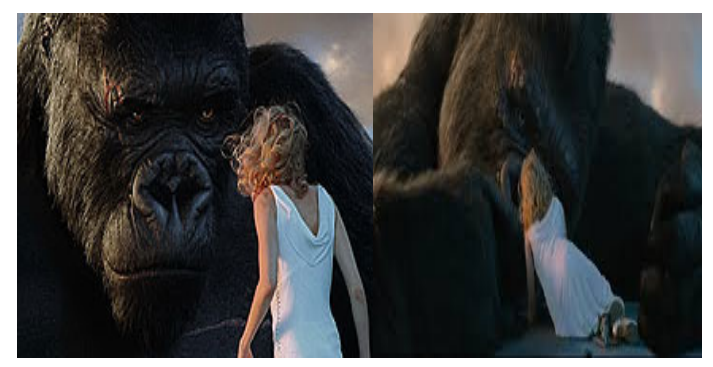

Figure 3. Kong's death on the top floor of the Empire State Building

The cinematic shots alternate between shots of both Kong's point of view as he gazes at Ann and her point of view as she gazes at him. As Kong is dying, the camera views the two from behind Ann; from the audience's point of view, the back of her head overlaps his left eye, while the direction of Kong's right eye indicates that he is looking at Ann. Although the audience sees Kong looking at Ann, the audience is looking more from her point of view than from his. Finally, between Kong's death and Jack's arrival, Ann is alone and the audience has no male protagonist with whom they can identify; instead, she is the focus. These scenes strengthen the audience's identification not with a male protagonist but with the heroine. Ann Darrow represents humanity and great nobility.

\section{Jackson's Cinematic Aura within the Adaptation Framework}

King Kong (2005) illustrates the influence of a filmmaker from former colonies on Hollywood cinema in Postcolonial era. Jackson gives a new identity to his new version to stand in contrast to the classic film of the Golden Age of Hollywood. Being the second does not mean that Jackson's version is subsidiary or inferior. Adaptation can be an autonomous work that can be interpreted and valued as such an adaptation has its own aura, its own "presence in time and space, its unique existence at the place where it happens to be" (Benjamin, 1968, p. 214). To take such a position, I seek to interpret "adaptation as an adaptation" (Hutcheon, 2006, p. 4), that is, my point of focus is to treat an adaptation as what Roland Barthes called "a plural stereophony of echoes, citation, references" (Barthes, 1977, p. 160).

The act of adaptation always "involves both (re-)interpretation and then (re-)creation"; this has been called both "appropriation and salvaging" (Hutcheon, 2006, p. 8) depending — in this context—on the filmmaker's perspective which is anti-colonial, compassionate and humanitarian. In The Fluid Text: A Theory of Revision and Editing for Book and Screen (2002), John Bryant argues that no text is a fixed thing; there are always a variety of manuscript versions, revisions and different print editions" (Bryant, 2002, pp. 1-2). In a parallel sense, films are likewise fluid, 
that is, Jackson's Postcolonial revision establishes a fluid relationship between a prior work and a belated one. Hutcheon explains that "the Postcolonial adaptations are, by definition, willful reinterpretation for a different context, even if the historical accuracy of the time and setting is retained" (Italics mine, Hutcheon, 2006, p. 153).

In "The Dialogics of Adaptation" (2000), Robert Stam believes that Film is usually said to be "the most inclusive and synthesizing" of performance forms: "A composite language by virtue of its diverse matters of expression-sequential photography, music, phonetic sound and noise - the cinema "inherits" all the art forms associated with these matters of expression... the visuals of photography and painting, the movement of dance, the décor of architecture, and the performance of theatre" (Stam, 2000, p. 61). In other words, King Kong proves to be a multi-track film through the use of camera angle, focal length, music, mise-en-scéne, performance and costumes. In King Kong (2005), the camera is deployed and positioned on Kong's - the male protagonist — chest and face to represent first-person point of view to create a mode of an intensity engagement. What is more important is Jackson's directorial control of intimacy and distance, the calibration of access to characters' knowledge and consciousness. The power of close ups creates a strong psychological intimacy reflecting inner thoughts and motivations.

Drawing on the degree of faithfulness to the original film, Michael Klein and Gillian Parker divide film adaptations into three main categories. The first group takes into consideration the viewers' expectations and therefore films within this category "attempt to give the impression of being faithful" (Klein \& Parker, 1981, p. 9). The second category includes film adaptations "that retain the core of the structure of the narrative while significantly reinterpreting or, in some cases, deconstructing the source [film]" (Klein \& Parker, 1981, p. 10). And the third group of film is one that "regards the source merely as raw material, as simply the occasion for an original work" (Klein \& Parker, 1981, p. 10). According to this typology, Jackson's 2005 remake of King Kong falls into the second category as Jackson has revisited the historical context of the 1933 film to provide a revisionist commentary on racial assumptions which spawned that same formative cinematic experience. Through the filmmaker's stylistic vision, meticulous recreation and with Conrad's Heart of Darkness, Jackson animates the myth of Kong within the Postcolonial paradigm.

Peter Jackson's King Kong (2005) immerses itself in the milieu of the 1930s Depression-era from its opening frames. He begins with shots of monkeys and then other exotic animals in a zoo. This touch of visual thematic foreshadowing shows primates in cages in the Central Park Zoo booth as an anticipation of Kong's eventual captivity. These captive animals are contrasted immediately with the shanty towns of the poor and unemployment in the park suggesting that the higher primates are no less imprisoned by socio-economic circumstances than the lower ones are by human racial whims. The grey and brown colors of the enclosures themselves, the run-down appearance of the buildings, the leafless and twisted trees, and the matte-like New York cityscape background tie the zoo's inmates to the poor shanty-town denizens nearby in the following frames.

\subsection{Deconstructing the 1933 Kong's Sexual Eroticism}

The 1933 Classic by Cooper depicts Kong's sexual desires through "the repeated use of the subjective camera in the Cave Sequence not only encourages us to identify with Kong, but also to interpret events from Kong's point of view" (Creed, 2007, p. 65). The curious Kong holds Ann and gently peels off strips of her clothing and with the other giant paw holds her torn clothing to his nostrils and sniffs her perfume. Ann looks at him with horror and then utters an indignant cry and Kong refuses to let her go proceeding to tickle her bare skin. The scene exposes Kong's monstrous eroticism as his encounter is characterized by touch and scent. It is through this sexual sensation that Ann and Kong are linked. Kong - through his erotic depiction-is given a voice, a point of view, as a terrifying monster.

The 1976 remake of King Kong by John Guillermin creates a different kind of screen animal from the original version. There was "a failure of imagination" that shows "the film's lack of poetry" (Creed, 2007, p. 70) because the mighty ape is an actor, Rick Baker, in an ape suit. The second version depicts an expedition party led by a representative of an oil company, Fred Wilson, to search for oil deposits at an uncharted location in the midst of the Indian Ocean. Wilson deploys Kong to promote the company's advertising event. The sexual scene is regarded as "the soft porn sequence" (Creed, 2007, p. 72). Kong carries a mud-spattered Dwan-the White heroine and Ann's counterpart - to a waterfall where he sits her in his giant leather paw and lets her wash herself clean. Dwan is "a product of the hippie seventies" (Creed, 2007, p.72) who talks too much when she becomes nervous. As Dwan realizes Kong's infatuation, she relaxes and begins to enjoy herself. Kong takes huge puffs of breath and gently blows her dry. Like his predecessor, Kong desires the White delicate woman, but now she does not reject him. Just as the scene verges on becoming too sexually explicit, a giant reptile slithers into the scene to ruin this erotic moment. The final cinematic scene illustrates Kong's death standing at the top of the World Trade 
Center. He is attacked by flame throwers as well as by biplanes spurting bullets. As he lies dying, his body is covered in bloody wounds; his eyes are filled with blood instead of tears.

The 2005 Kong's eyes and face convey pride, valor and intelligence whose feeling for Ann is less erotic seeking only companionship. The sexual scene in Kong's cave is totally different. The point of view shots alternate between both Ann and Kong mirroring their emotional bond and the viewers' identification with both the male and female protagonists. To pacify his anger, Ann breaks into vaudeville routine. Kong beats his chest as he is greatly amused and wants more. Ann juggles and leaps while Kong knocks her over and grunts with pleasure at her loss of balance. "Stop! No", the fearless Ann yells, "there isn't any more!". As the plot proceeds, Kong rescues her from giant prehistoric creatures. "Wait", Ann cries and he picks her up and slings her over his massive shoulder. Back to the cave, Ann juggles and together they watch the sunset. "It is beautiful" signifies an enchanting and charming moment. As two companions, they cherish the "rhythm of time and nature" (Creed, 2007, p.74). This moment is revisited in New York when the two friends slide playfully together across the ice in the Central Park. The final sequence signifies the loss of innocence and the end of the human-animal bond.

\subsection{Ann Darrow's Gender Role in the 2005 Remake King Kong}

Jackson's 2005 King Kong presents a relationship between Ann (Naomi Watts in this version) and Kong that is altogether different from the original 1933 film. The initial way in which this is done is by modernizing the gender role of the Ann Darrow character. While Fay Wray's portrayal may have been the archetypal damsel in distress in early twentieth century cinema, Jackson astutely depicts Ann Darrow—who is a vaudeville performer struggling for her livelihood - to be more faithful to the image of the Post-World War II, Post-Women's Liberation. She is tempted, but she refuses to debase herself by doing striptease. She is inspired by the work of Jack Driscoll who is a social dramatist. When she comes face to face with Kong, she is obviously initially terrified, but in a later scene where he entertains himself by pushing her to the ground, she angrily tells him to stop which he reluctantly obeys. Ann is a strong, independent, and intelligent character far more likely to generate empathy amongst a modern female audience than the helpless Fay Wray.

The relationship is further cemented in an extraordinary action sequence that climaxes with Ann stuck between a hungry T-Rex and Kong. As the combatants face off, Ann chooses to move beneath Kong declaring him as her protector who courageously unhinges the T-Rex's jaw-set. From this moment on, Kong is her champion. They retreat to a high-mountain refuge. There, the sunset opens up before them, and Ann, contemplating both it and the gorilla, beats softly on her chest and calls it "beautiful". It is also a tender allusion to the film's climax when Kong, scared and cornered, again retreats with Ann to the highest perch he can find, this time atop the Empire State Building. There, the night passes into twilight and in the face of the rising sun Kong beats slowly on his own chest, signaling that he has understood both the beauty in the world and Ann's allusion to it. Ann and Kong have learned to step outside their own subjective existence and to relate to each other.

It is through her eyes that the audience sees Kong, as a beautiful giant as opposed to a big hairy monster. Instead of screaming whenever he is on screen, for instance, she watches the sunset with him and sleeps in his hand:

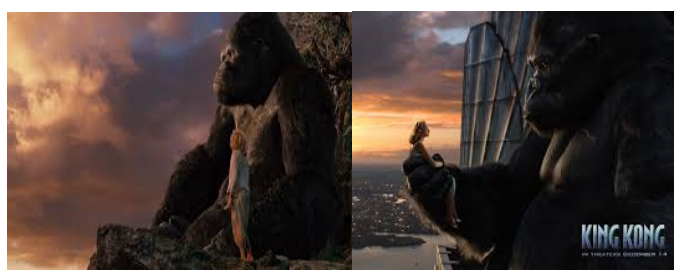

Figure 4. The sunset scenes: the first in Kong's cave and the second on the floor of the Empire State Building

The creation of the deeply sentient Kong allows for a complex emotional relationship that is almost entirely wordless. The pair is given the most aesthetically and emotionally touching scenes of the film, and it is that beauty combined with Ann's strength of character and Kong's emotional vulnerability that offers a revolutionized perspective on the perceived relationship between Black man and White woman. It offers up the image of that relationship as something natural and unproblematic, cruelly interrupted by the White man's urge to destroy. By focusing the cinematic gaze on Kong through Ann's eyes rather than the White man's, we are given more intimate portrait of the iconic primate: 


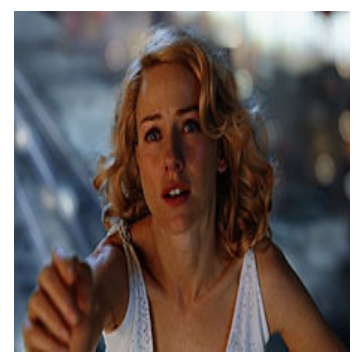

Figure 5. Ann's humanitarian cinematic gaze

Ann and Kong interrupt the White man's urge to capture, exploit, and destroy with images of tenderness and love. The 2005 film is expressively about its own time incorporating within itself a relationship with the historical time it depicts. In this sense, the film offers up a commentary on the racial terror that stemmed from Ann's and Kong's relationship in the original, replacing Fay Wray's superficial fear with a humanized bond that is deeper than any other relationship in the film. This ultimately portrays the most significant appropriation of the 1933 story to the 2005 screen. By the end of the 1933 version, the audience wants Kong to be killed for destroying their city and stealing their woman. In the 2005 version, the audience watches in terrible anticipation the death of Kong whom they have loved through Ann's eyes. The 2005 King Kong criticizes the racist ideologies of the original film sentimentalizing the relationship between Kong and Ann.

Surviving the Depression in New York, Ann juggles across a vaudeville stage. Pale and scrappy, dressed like Chaplin, Ann smiles and in her charming flapper's hat and shabby coat, she spends only a moment looking in the window of a burlesque house, then turns away, determined to maintain her goodness rather than sell herself cheap. What sets the new film apart from its predecessor is its characterization of Ann and especially her admiration for Kong. Her evolving affection for Kong as manifested in her efforts to appease him, dancing and juggling is different from the worship acted out by the natives who sacrifice her to him with ropes, rattles and pounding drums.

Rather than fearing Kong, Ann comes to respect and care for him. They gaze on a sunset from a top Skull mountain and slide playfully on an icy lake in the Central Park. The scenery of the ice and the white snow show Kong's beauty and his soft looks whereas they reflect Denham's meanness and black bestiality. She is so horrified by Denham's pains to chain and display him. Denham reduces the beast to a life bound by chains and reenacts his capture for the city's selfish entertainment that proves to be cruel, brutal and less human.

\subsection{Carl Denham in Jackson's Adaptation}

The focal point for the 2005 King Kong's critique of American Capitalist exploration is the figure of Carl Denham. He is the indefatigable huckster filmmaker who exploits the Otherness of the giant ape for the basest of selfish aims. Played by the comic actor Jack Black, this version of Denham is a caricature of Robert Armstrong's original character. Jackson does not view the fundamental drives of the American male in the same positive light adopted by Cooper whose Denham is personified as an American hero. Jackson's status as an open-minded filmmaker from New Zealand, a country with a problematic colonial history, drives him to reject the arrogant racial ideologies adopted by Cooper's Denham. Denham's fantasy of ethnographic control reflects his exploitation of the "Other" for his racial fantasy. This underscores the overall sympathy for the creature of the exotic realm. This different approach to Carl Denham is one of the most thematic distinctions between Cooper's and Jackson's films as I envisioned in the following diagram:

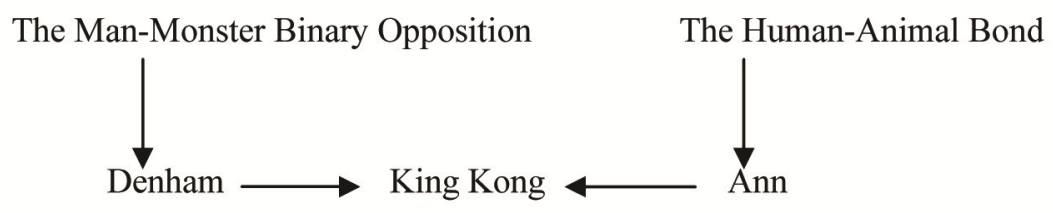

Figure 6. Jackson's postcolonial approach to King Kong (2005)

Denham - as a man of city - is out of touch with Nature and consequently out of touch with ethics. As a schemer and deceitful, Denham uses not only Kong but every human being around him to achieve wealth and fame 
entirely for him and him alone. The voyage represents the pinnacle of his career; the fulfillment of his greatest dream, that is, to make the greatest picture in the world. Denham convinces Miss Darrow to join the film crew calling her "the saddest girl I've ever met". He also tricks earnest playwright Jack Driscoll and captain Englehorn to crash into Skull Island. Denham also finds a way to turn the loss of his crew members into reasons to go on, as he insists that each dies "doing what he loves, and so must be remembered by completing the projecting and "donating the proceeds to his wife and children". However, he is a leech and immoral entrepreneur with no sense of personal accountability.

The elegant montage of contemporary life in the city featuring vignettes of congested traffic, homelessness and protest marches accompanied ironically by Al Jolson's recording of "I'm sitting on Top of the World" signify the forthcoming exotic adventures not as an escape from the harsh economic realities, but as an unavoidable consequence of the relentless competitive demands of American capitalism. In order to avoid being exploited by such a ruthless system, Denham is decided to adopt such a greedy character; devious and fraudulent. It is survival of the fittest in urban civilization as well as in the jungle. In a word, Denham is overthrown by his own ethnographic fantasies and capitalistic pursuits.

\section{Conclusion}

The current study tackles the tragedy of twenty-first century fairy tale watched by postmodern audience whose identification with the 2005 Kong as an actor is fulfilled through a postcolonial approach to Animalization and Exoticism to defy colonial hegemony. Animal studies can offer new interpretations of how nonhuman animals can deconstruct ontological Western discourses of rationality and capitalism within Postcolonial Cinema to rethink the boundaries that separate human and nonhuman by engaging ethically with nonhuman animals through films and literatures. In the seventy-two years that separate the release of both the King Kong films, the world has witnessed the Civil Rights Movement, Martin Luther King's dream coming true in the Civil Rights Act, the election of the first black President, and other countless milestones in creating equality in America. By revisiting Cooper's iconic story and images, the 2005 King Kong appropriates the perceived racism of the original story to the modern world by humanizing Kong and his relationship with Ann Darrow. Jackson underscores the Kong-Ann friendship and it is one of his most significant cinematic visions as manifested in the behavior of both of them - from their first terrifying meeting to their last tearful departure. The film techniques and narrative details that portray Kong's interaction with the heroine Ann Darrow force the audience to identify with a nonhuman animal as though he were a typical male protagonist. At the outset, Peter Jackson's King Kong reinforces the Other-ness of a Congo-like atmosphere and the human male dominance. Yet, as the film progresses, a growing identification with Kong collapses the "Othering" initiated in the beginning of the film. Finally, Jackson transcends the socio-racial limitations to create new cinematic spaces for resistance and disruption of ontological categories imposed by colonial ideologies and to destabilize and expose the notion of Whiteness within the Black-Ape association.

\section{References}

Achebe, C. (2001). An Image of Africa: Racism in Conrad's Heart of Darkness. In V. B. Leitch (Ed.), The Norton Anthology of Theory and Criticism (pp. 1783-1794). New York: W. W. Norton \& Company.

Ahuja, N. (2009). Postcolonial Critique in a Multispecies World. PMLA, 124(2), 556-563. https://doi.org/10.1632/pmla.2009.124.2.556

Armstrong, P. (2002). The Postcolonial Animals. Society and Animals, 10(4), 413-419. https://doi.org/10.1163/156853002320936890

Armstrong, P. (2008). What Animals Mean in the Fiction of Modernity. London: Routledge.

Ashcroft, B. et al. (1989). The Empire Writes Back: Theory and Practice in Postcolonial Literature. London: Routledge. https://doi.org/10.4324/9780203426081

Ashcroft, B. et al. (2000). Postcolonial Studies: The Key Concepts. London: Routledge.

Ashcroft, B. et al. (2002). The Empire Writes Back: Theory and Practice in Postcolonial Literature (2nd ed.). London: Routledge.

Barthes, R. (1977). Image-Music-Text. In S. Heath (trans.). New York: Hill \& Wang.

Bekoff, M. (2007). The Emotional Lives of Animals. Novato, CA: New World Library.

Benjamin, W. (1968). Illuminations. Hannah Arendt, NY: Harcourt, Brace \& World.

Bennett, A., \& Nicholas, R. (2009). An Introduction to Literature, Criticism and Theory. London: Pearson, 
Longman.

Bhabha, H. (1994). The Location of Culture. New York: Routledge.

Boehmer, E. (1995). Colonial and Postcolonial Literature. Oxford: Oxford University Press.

Bordwell, D., \& Thompson, K. (1993). Film Art: An Introduction. New York: McGraw-Hill, Inc. International Edition.

Bryant, J. (2002). The Fluid Text: A Theory of Revision and Editing for Book and Screen. Ann Arbor: University of Michigan Press.

Burt, J. (2002). Animals in Film. London: Reaktion Books. https://doi.org/10.3998/mpub.12024

Carroll, N. (1984). King Kong: Ape and Essence. Planks of Reason: Essays on the Horror Film (pp. 215-244). Metuchen, New York \& London: The Scarecrow Press.

Carroll, N. (1990). The Philosophy of Horror: or Paradoxes of the Heart. New York: Routledge.

Conrad, J. (1988). Heart of Darkness. New York: W.W. Norton and Company, Inc.

Cooper, M., \& Schoedsack, E. (1933). King Kong. Radio Pictures, 100 min.

Creed, B. (2007). "What Do Animals Dream of? Or King Kong as Darwinian Screen Animal. In L. Simmons \& P. Armstrong (Eds.), Knowing Animals (pp. 59-78). Leiden, Boston: Brill. https://doi.org/10.1163/ej.9789004157736.i-296.29

Darwin, C. (1871). The Descent of Man and Selection in Relation to Sex. London: John Murray.

Deleuze, G., \& Guattari, F. (1987). A Thousands Pleasures: Capitalism and Schizophrenia. Minneapolis \& London: University of Minnesota Press.

Dias, B. (2013). "The Return from Otherness: Hegel's Consciousness in the Phenomenology of Spirit". Otherness Essays and Studies, 4(1), 1-2. Retrieved from http://www.otherness.dk/filedadmin/www.othernessandhearts.org/Publications/Journal_Otherness/Othernes s_Essays_and_Studies_4.1/Hegel_Otherness.pdf

Erb, C. (1998). Tracking King Kong: A Hollywood Icon in World Culture. Michigan: Wayne State University Press.

Fudge, E. (2002). Animal. London: Reaktion Books.

Gregersdotter, K. et al. (2015). Animal Horror Cinema: Genre, History and Criticism. Palgrave: Macmillan. https://doi.org/10.1057/9781137496393

Guillermin, J. (1976). King Kong. Paramount Pictures, 129 min.

Haraway, D. (1989). Primate Visions: Gender, Race and Nature in the World of Western Science. N. Y.: Routledge.

Hutcheon, L. (2006). A Theory of Adaptation. New York/London: Routledge.

Jackson, P. (2005). King Kong. Universal Pictures, 180 min.

Kaplan, E. A. (1997). Looking for the Other: Feminism, Film and the Imperial Gaze. New York/London: Routledge.

Klaw, R. (2005). “King Kong (1933)”. In G. Westfahl (Ed.), The Greenwood Encyclopedia of Science Fiction and Fantasy: Themes, Works and Wonders (pp. 1122-1124). Westport: Greenwood Press.

Klein, M., \& Parker, G. (1981). The English Novel and Movies. New York: Ungar Publication.

Lippit, A. M. (2000). Electric Animal: Towards Rhetoric of Wild Life. Minneapolis, London: University of Minnesota Press.

Lupoff, R. (2005). Kong is Us. In K. Haber (Ed.), Kong Unbound: The Cultural Impact, Pop Mythos and Scientific Plausibility of a cinematic Legend (pp. 25-42). New York: Pocket Books.

Manlove, C. (2012). An Image of Africa: Representation of Modern Colonialism in Africa in Peter Jackson's King Kong. In M. E. Higgins (Ed.), Hollywood's Africa After 1994 (pp. 125-141). Athens: Ohio University Press.

Mohanty, C. T. (2003). Feminism without Borders: Decolonizing Theory, Practicing Solidarity. London: Duke University Press. https://doi.org/10.1215/9780822384649

Morton, R. (2005). King Kong: The History of a Movie Icon from Fay Wray to Peter Jackson. New York: 
Applause Theatre \& Cinema Books.

Mulvey, L. (1975). Visual Pleasure and Narrative Cinema. Screen, 16(4), 6-18. https://doi.org/10.1093/screen/16.3.6

Neale, S. (1980). Genre. London: British Film Institute.

Pratt, M. L. (1992). Imperial Eye: Travel Writing and Transacculturation. New York: Routledge.

Rice, A. (2003). Radical Narratives of the Black Atlantic. London: Continuum.

Rony, F. (2000). King Kong and the Monster in Ethnographic Cinema. In K. Gelder (Ed.), The Horror Reader. London: Routledge.

Russell, D. J. (1998). Monster Round-Up: Reintegrating the Horror Genre. In N. Browne (Ed.), Refiguring American Film Genre: History and Theory. California: California Press.

Said, E. (1994). Culture and Imperialism. London: Vintage.

Shohat, E. \& Stam, R. (1994). The Imperial Imaginary. Unthinking Eurocentrism: Multiculturalism and Media (pp. 100-136). New York: Routledge.

Singer, P. (1975). Animal Liberation. New York: Random House.

Smith, V. (2008). Uneven Development: Nature, Capital and the Production of Space. Athens, GA: University Georgia Press.

Sorenson, J. (2009). Ape. London: Reaktion Books Ltd.

Spivak, G. (1993). Can the Subaltern Speak?. In P. Williams \& L. Chrisman (Eds.), Colonial Discourse and Postcolonial Theory: A Reader (pp. 66-111). New York: Columbia University Press.

Stam, R. (2000). Film Theory: An Introduction. Oxford: Blackwell Publishers.

Stam, R. (2000). The Dialogics of Adaptation. In J. Noremore (Ed.), Film Adaptation (pp. 54-76). New Brunswick, N. Y.: Rutgers University Press.

Stam, R. et al. (1992). New Vocabularies in Film Semiotics: Structuralism, Poststructuralism and Beyond. London: Routledge.

Telotte, J. (1988). The Movies on Monsters: Seeing in King Kong. The Georgia Review, 42(2), 388-398.

Thieme, J. (2001). Postcolonial Con-texts: Writing Back to the Canon. London: Continuum Intl Pub. Group.

Torgovnick, M. (1990). Gone Primitive: Savage Intellects, Modern Lives. Chicago: University Chicago Press.

Young, R. (1995). Colonial Desire: Hybridity in Culture, Theory and Race. London \& New York: Routledge.

\section{Copyrights}

Copyright for this article is retained by the author, with first publication rights granted to the journal.

This is an open-access article distributed under the terms and conditions of the Creative Commons Attribution license (http://creativecommons.org/licenses/by/4.0/). 